\title{
Higher vibration modes in railway tracks at their cutoff frequencies
}

\section{Doctoral Thesis}

Author(s):

Pfaffinger, Markus R.

Publication date:

2000

Permanent link:

https://doi.org/10.3929/ethz-a-004037277

Rights / license:

In Copyright - Non-Commercial Use Permitted 
Diss. ETH No. 13755

\title{
Higher Vibration Modes in Railway Tracks at their Cutoff Frequencies
}

\author{
A thesis submitted to the \\ SWISS FEDERAL INSTITUTE OF TECHNOLOGY \\ for the degree of \\ Doctor of Technical Sciences
}

presented by

Markus R. Pfaffinger

Dipl. Masch.-Ing. ETII

born July 29, 1970

citizen of Maur, $\angle H$

and Rhode Island, USA

Accepted on the recommendation of

Prof. Dr. J. Dual, examiner

Prof. Dr. P. Hagedorn, coexaminer

Zürich, 2000 


\section{Abstract}

This thesis examines forced vibrations of railway tracks excited at the cutoff frequency of one of its wave modes. The system response of higher modes was studied theoretically, numerically and experimentally in the frequency range from $5 \mathrm{kHz}$ to $50 \mathrm{kHz}$. The background of this work is the question, whether the vibration field close to the excitation could be used as a detection principle for passing train wheels. A feasibility study preceding this work showed a strong interaction between passing wheels and forced rail vibrations but also raised a number of questions regarding the reliability of a sensor based on this idea.

The rail can be considered as a discretely supported, quasi-infinite waveguide. In the first part of this work containing theoretical considerations, a general study on the forced system response of a waveguide including higher modes and modal damping was performed. This investigation was done with the help of a model consisting of several elastically connected beams with modal damping. It was shown, that the amplitude of the response reaches maxima at the cutoff frequencies. The cutoff frequencies and mode shapes correspond to the solutions of an eigenvalue problem associated with the cross-section of the waveguide. This knowledge allowed the numerical calculation of the modes of the actual rail, at which the experiments were carried out. The multiple mode model revealed, that the cutoff frequencies and mode shapes of higher modes are hardly influenced by support parameters. Although the experimentally determined system response exhibits a high level of complexity, these findings permitted a specific search for the modes of the test track at the numerically predicted cutoff frequencies and made it possible to visualize the corresponding mode shapes of the real rail.

With the help of the multiple mode model actuated at one of its cutoff frequencies, it was shown that the system deformation is dominated by the corresponding mode shape close to the excitation. System damping and frequency control the size of this so-called local vibration zone. At greater distances from the excitation, lower wave modes, propagating with small attenuation rates, become increasingly important to the system response. These characteristics are also demonstrated within the experimental investigation.

Additional amplitude maxima originating from the discrete support are not considered to be suitable for wheel detection because of their lack of a local vibration zone and are therefore only dealt with in passing.

System damping was shown to be a key parameter regarding the spatial extent of the local vibration zone, the amplitude and the time constant of the system response. An experimental concept commonly used to characterize system damping is the so-called quality factor or Q-factor. Using the model of a Ber- 
noulli-Euler beam on a viscoelastic foundation, it was, however, pointed out, that there are some important differences to be considered for a system which both resonates and interacts with traveling waves. A modification of the $Q_{\text {- }}$ factor definition is proposed for this case. Experiments were carried out at the test track in order to determine the quality factors of a number of modes. The results obtained from different measurement methods showed a moderate correspondence, which was partially attributed to the complexity of the studied system. For this reason, the achieved accuracy of the quality factor values seemed reasonable.

The influence of passing train wheels was studied theoretically with the help of the multiple mode model. It was shown, that the observed effect depends on the position of the wheel contact point and of the receiving transducer within the rail cross-section. It must be avoided, that neither is located at a node of the cross-sectional vibration. Since the position of the wheel contact on the running surface is undefined, a vibration mode without nodes at the rail head must be chosen for wheel detection.

A movable bogie was used to experimentally investigate the influence of passing train wheels on forced rail vibrations. Although these measurements in general confirmed the previous statements, the overall reaction appeared to be insufficient to be analyzed for single train wheels by an electronic device. The moderate interaction between the vibration and the wheel was explained by the low axle weight of the bogie used. Although the unloaded bogie can be considered as the worst case regarding axle load, even here an unconditional axle detection must be demanded by a sensor operating within a safety relevant system.

Based on the acquired knowledge, the studied detection principle cannot be recommended for the use within a general-purpose wheel sensor. The required safety standard cannot be achieved because of the insufficient reaction time of the mechanical system and the uncertainty whether the excited vibration is suitable for wheel detection. However, the concluding chapter proposes some more specific applications of forced vibrations of waveguides and some ideas for future research on this topic are outlined. 


\section{Zusammenfassung}

In dieser Arbeit werden erzwungene Schwingungen von Eisenbahnschienen erforscht, welche bei ihren Cutoff Frequenzen angeregt werden. Die Systemantwort von höheren Modes im Frequenzbereich von $5 \mathrm{kHz}$ bis $50 \mathrm{kHz}$ wurde theoretisch, numerisch und experimentell untersucht. Insbesondere soll die Frage beantwortet werden, ob das Schwingungsfeld nahe der Anregung zur Detektion von Eisenbahnrädern genülzı werden könnte. Eine zuvor durchgeführte Machbarkeitsstudie zeigte, dass erzwungene Schienenschwingungen durch darïberfahrende Zugsräder beeinflusst werden. Es wurden allerdings auch Fragen bezüglich der Zuverlässigkeit eines auf diesem Prinzip beruhenden Sensors aufgeworfen.

Die Schiene kann als ein diskret gelagerter, unendlich langer Wellenleiter betrachtet werden. In einem ersten Teil dieser Arbeit, welcher theoretische Überlegungen enthält, wurde eine grundsätzliche Studie über erzwungene Schwingungen in Wellenleitern durchgeführt. Diese Untersuchung wurde an einem Modell bestehend aus mehreren elastisch verbundenen Balken vorgenommen, womit höhere Modes und modale Dämpfungen mit eingeschlossen werden konnten. Es wurde gezeigt, dass die Amplitude der Systemantwort bei den Cutoff Frequenzen Maxima erreicht. Die Cutoff Frequenzen und die dazugehörenden Schwingungsformen entsprechen den Lösungen eines Eigenwertproblems des Wellenleiterquerschnitts. Dieses Wissen erlaubte die numerische Berechnung der Schwingungsformen der tatsächlichen Schiene, an welcher die Experimente durchgeführt wurden. Untersuchungen am Multiple Mode Model zeigten, dass die Cutoff Frequenzen und Schwingungsformen von höheren Modes kaum durch Parameter der Lagerung beeinflusst werden. Obwohl die experimentell bestimmte Systemantwort einen hohen Grad an Komplexität aufweist, ermöglichte diese Erkenntnis die gezielte Suche nach bestimmten Modes des Testgleises in der Nähe der numerisch vorhergesagten Frequenzen und erlaubte damit die Visualisierung der entsprechenden Schwingungsformen der realen Schiene.

Anhand des Multiple Mode Models, welches bei einer seiner Cutoff Frequenzen angeregt wurde, konnte gezeigt werden, dass die Systemantwort nahe der Anregung von der entsprechenden Schwingungsform dominiert wird. Die Systemdämpfung und die Frequenz bestimmen die Grösse dieser sogenannten lokalen Schwingungszone. Mit wachsendem Abstand von der Anregung bekommen tiefere Wellenmodes, welche sich mit kleinen Abklingraten ausbreiten können, einen zunehmenden Einfluss auf die Systemantwort. Diese Eigenschaften konnten auch bei den Experimenten beobachtet werden.

Zusätzliche Amplitudenmaxima, welche aufgrund der diskreten Lagerung entstehen, werden wegen des Fehlens einer lokalen Schwingungszone bezüglich Achsdetektion als ungeeignet angesehen und werden deshalb nur am Rande 
behandelt.

Die Systemdämpfung wurde als einer der Hauptparameter identifiziert, welcher die örtliche Ausdehnung der lokalen Schwingungszone, die Amplitude und die Zeitkonstante der Systemantwort beeinflusst. Eine gebräuchliche Messmethode zur Bestimmung der Dämpfungen ist der sogenannte Qualitätsfaktor oder Q-Faktor. Anhand des Modells cines viskoelastisch gebetteten Bernoulli-Euler Balkens konnte allerdings gezeigt werden, dass bei einem resonanten System, welches Wellenausbreitung mit einschliesst, einige signifikante Unterschiede berücksichtigt werden müssen. Eine Anpassung der Q-Faktor Definition wird für diesen Fall vorgeschlagen. Die Qualitätsfaktoren von mehreren Schienenmodes wurden experimentell bestimmt. Die mit verschiedenen Messmethoden erhaltenen Resultate zeigten eine mässige Übereinstimmung, was teilweise auf die hohe Komplexität des untersuchten Systems zurückgefüht wurde. Aus diesem Grund erscheint die erreichte Genauigkeit für die Qualitätsfaktoren vernünftig.

Der Einfluss eines Zugsrades wurde am Multiple Mode Model theoretisch diskutiert. Es wurde gezeigt, dass der beobachtete Effekt davon abhängt, an welcher Position auf dem Schienenprofil sich der Kontaktpunkt des Rades und der Empfänger befinden. Keiner von beiden sollte auf einem Knoten der Querschnittsschwingung zu liegen kommen. Da die genaue Lage des Radkontaktes auf der Lauffläche undefiniert ist, müssen für die Raddetektion Modes gewählt werden, welche keine Schwingungsknoten am Schienenkopf aufweisen.

Ein motorisiertes Drehgestell wurde verwendet, um den Einfluss von Zugsrädern auf erzwungene Schienenschwingungen experimentell zu untersuchen. Diese Messungen bestätigten im Wesentlichen die oben gemachten Aussagen. Allerdings musste festgestellt werden, dass der beobachtete Effekt zu gering war, um es einer Auswertungselektronik zu ermöglichen, einzelne Zugsräder zu erkennen. Die wenig ausgeprägte Wechselwirkung zwischen der Schwingung und den Rädern wurde durch die geringe Achslast des verwendeten Drehgestells erklärt. Obschon ein einzelnes Drehgestell die ungünstigste Konfiguration bezüglich Achslast darstellt, muss auch in diesem Fall eine einwandfreie Achsdetektion von einem Sensor gefordert werden, welcher innerhalb eines sicherheitsrelevanten Systems eingesetzt werden soll.

Aufgrund der gewonnenen Erkenntnisse kann das untersuchte Verfahren nicht zur Achsdetektion im Rahmen eines Allzwecksensors empfohlen werden. Die geforderte Zuverlässigkeit kann nicht erreicht werden, da die Reaktionszeit des mechanischen Systems ungenügend ist und weil nicht garantiert werden kann, dass die angeregte Schienenschwingung für die Raddetektion geeignet ist. Im abschliessenden Kapitel werden allerdings einige spezifischere Anwendungsmöglichkeiten von erzwungenen Schwingungen in Wellenleitern vorgeschlagen und es wird ein Ausblick auf mögliche künftige Forschung auf diesem Gebiet gegeben. 